\title{
Thinking About Competitive Balance
}

\section{by}

\author{
Allen R. Sanderson and John J. Siegfried
}

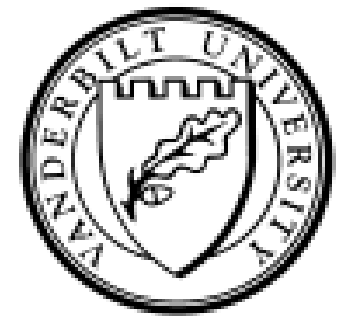

Working Paper No. 03-W18

September 2003

\section{DEPARTMENT OF ECONOMICS \\ VANDERBILT UNIVERSITY \\ NASHVILLE, TN 37235}

www.vanderbilt.edu/econ 


\section{Thinking About Competitive Balance}

\section{Allen R. Sanderson, University of Chicago, and John J. Siegfried, Vanderbilt}

\section{University $^{1}$}

\section{INTRODUCTION}

Within the last decade, the business of American professional team sports has seen contentious strikes and lockouts, escalation of players' salaries, multi-million dollar television and cable-rights contracts, increased melding of sports and entertainment, new expansion teams, bitter franchise relocations, and an explosion in the construction of publicly-financed facilities. In an era in which inequalities of wealth and opportunity are constantly at the forefront of public-policy discussions in the United States, in the world of professional sports many high-profile economic events also seem to turn on issues of inequality: between owners and players over the distribution of economic rents; among owners over the distribution of gate receipts, broadcast revenues, and talent; and between mayors, taxpayers, owners and league officials over figurative level playing fields with regard to the provision of state-of-the-art venues.

With regard to baseball, the re-emergence of the New York Yankees as a dynasty in the post-strike period of the last decade - four World Series championships in a fiveyear period (1996-2000), winning 116 games in 1998, and payrolls that dwarfed those of most opponents - contributed as much as anything to the perception of an injurious competitive imbalance problem. The Yankees' loss in the 2001 World Series, the 2002 four-year collective bargaining agreement between Major League Baseball (MLB) and the players' union, which included measures designed to produce more balance, and/or the first-ever all-wild-card World Series in 2002 (with the two teams' combined payrolls 
equaling the Yankees') will likely not dampen enthusiasm for the topic among fans in bars or on sports talk radio, by media commentators or by sports economists and statisticians doing their analyses.

Simon Rottenberg (1956) long ago noted that "the nature of the industry is such that competitors must be of approximately equal 'size' if any are to be successful; this seems to be a unique attribute of professional competitive sports." $(242)^{2}$ While the absolute quality of play influences demand and absolute investments in training are socially efficient (Lazear and Rosen, 1981), the relative aspects of demand and quality of competition also loom large in sports. In cases when consumer demand depends to a large extent on inter-team competition and rivalry, the necessary interactions across "firms" (i.e., teams) define the special nature of sports. Contests among poorly matched competitors would eventually cause fan interest to wane and industry revenues to fall. But potential "arms races" - or "rat races" - are possible, and maybe even inevitable (Akerlof, 1976). ${ }^{3}$

In the 1990 s and early $21^{\text {st }}$ century, while some social scientists wrung their hands over apparent widening inequality of income in the United States and between developed and third-world nations, sports economists, commentators, fans and owners (at least among the also-rans) lamented the perceived widening inequality of wealth and championships among teams, especially the large-market, high-revenue, and/or highpayroll teams versus their country-cousin kin in baseball. ${ }^{4}$ The distribution of playing talent, team revenues and salary expenditures, and competitive balance dominate sports and sports-business conversations whenever a team with the highest payroll, or an owner with the deepest pockets or a decidedly different utility function, wins a championship; or 
whenever a franchise extracts a new publicly-funded ballpark from its community on the threat of relocating; or when an apparent dynasty emerges, such as the New York Yankees in recent years or another NL-East division title for the Atlanta Braves. ${ }^{5}$

Even before the baseball season began in 1999, the league adopted the mantra, reiterated upon seemingly every public occasion (with the uncritical assistance of the sports media) that few of baseball's franchises actually stood a chance of being in the World Series in the fall. In a Wall Street Journal column that year, San Diego Padres' chairman John Moores, whose team was swept 4-0 by the Yankees in the 1998 World Series and then traded away much of its top talent, echoed these sentiments:

"The Major League Baseball season began yesterday, and fans everywhere are hoping their team will make it to the World Series. But the sad fact is that many teams are chronically uncompetitive. Perhaps 12 of the 30 Major League teams have any possibility of reaching postseason play, and fewer still have a realistic hope of winning a pennant. Unless baseball changes the way it does business, it risks seeing its fans drift away, tired of their teams' futility.",

Also in 1999, baseball commissioner Allan H. "Bud" Selig convened a panel of well-known individuals ${ }^{7}$ to study the impact of revenue disparities on competitive balance. It produced a lengthy report, The Commissioner's Blue Ribbon Report on Baseball Economics (Levin et al, 2000), that noted large and growing revenue disparities, which, in turn, affected balance. ${ }^{8}$ In addition to more quantitative theoretical and empirical measures of competitive balance (see below), the Blue Ribbon panel also defined competitive balance qualitatively:

"In the context of baseball, proper competitive balance should be understood to exist when there are no clubs chronically weak because of MLB's financial structural features. Proper competitive balance will not exist until every well-run club has a regularly recurring hope of reaching postseason play." (page 5) 
Broadcaster Bob Costas chimed in with similar laments (Costas, 2000). Major League Baseball conducted a national poll of 1,000 fans in late 2001 that purported to indicate that competitive imbalance was a serious problem in the minds of 75 percent of respondents; 42 percent of them indicated they would lose interest in the game were more teams not to have a realistic chance of winning. Summarizing the results, Sandy Alderson, MLB's Executive Vice President, said: "We have a competitive-balance problem. This is something the average fan cares about. They don't care if owners are losing money. They do care if it translates into negative consequences for their teams." ${ }^{9}$

Although certainly not unique to this particular period or sport, the complaint of woeful imbalance has become more common in the last few years, with the lack of significant revenue sharing or a firm payroll cap in Major League Baseball (MLB) relative to the National Football League (NFL) identified as the culprits. Increased player freedoms, through which an owner could hire the best players and, at least in the short run, buy a championship, is seen as an accomplice. Apart from the obvious owners' interest in limiting bidding for players, and the equally obvious interest among players in that not being allowed to occur, payroll caps, salary caps, luxury taxes, increased revenue sharing and restructured draft systems are touted as ways to constrain competition and thus improve competitive balance among teams. ${ }^{10}$ League restrictions on both the geographical relocations of teams and the mobility of players across teams, in addition to having more self-serving purposes, also affect balance. A more radical proposal was the commissioner's recent threat to contract baseball by as many as four teams.

In the sections below we attempt to lay out what one might mean by competitive balance, review the theoretical and empirical scholarship and popular contributions with 
regard to its various dimensions, describe the natural forces and considerations, as well as institutional rules and regulations that contribute to observed distributions of playing performances. We also compare at various junctures the situation in baseball versus other sports leagues, including college athletics, and individual sports.

\section{COMPETITIVE BALANCE IN THEORY AND PRACTICE}

Every sport and sports league has had to confront the fundamental issue of relative strengths among competitors. There has not been a uniform, one-size-fits-all approach or set of rules to resolve this problem. Inasmuch as uncertainty of outcome is a key component of fan demand, wide disparities in inputs, and thus in likely outcomes, are seen as inimical to the long-term health and financial viability of the individual enterprise. How to handle weak teams or inferior opponents - to prevent lower quality competitors from free-riding on higher quality rivals - can be as much or more of a problem as dealing with perennially strong ones, because there is at least some interest in seeing the very best individual performers and teams. ${ }^{11}$

Boxing segments fighters into weight classes and employs rankings and ladders to create bouts with equally matched opponents. Auto racing, track competitions and swimming use qualifying times to ensure competitive fields. Tennis produces seedings, based on previous performances, in the expectation that the strong will play the strong in later-round matches. "Claiming races" in thoroughbred racing is a mechanism designed to have horses of approximately equal ability entered into the same event. Except for the occasional novelty or promotion, women do not compete against men. Periodic structural changes or modifications in the rules of play, such as elimination of the center-jump and 
adoption of a shot clock in basketball, or altering the height of the mound or changing the effective strike zone in baseball, have been used to tilt the playing field to achieve a certain objective and to prevent some competitors from exploiting particular advantages or decreasing fan interest in the contests. Another example is restrictions on athletes' use of performance-enhancing substances.

The theory of competitive balance in team sports was first developed by Rottenberg (1956). ${ }^{12}$ While not a direct contribution to the sports-economics literature, concepts in Ronald Coase's "The Problem of Social Cost" (1960) have been applied to reserve clauses, reverse-order draft systems, and player free agency as they affect, or fail to influence, playing strengths and the reallocation of player resources. ${ }^{13}$ Since that time, economists have contributed rigorous theoretical and empirical work on various aspects of competitive balance (Daly and Moore (1981), Gerald Scully (1989 and 1995), Quirk and Fort (1992, 1995, and 1999), Zimbalist (1992), Dobson and Goddard (2002, Chapter 3)), including formal measures of balance within a league (such as the dispersion of wonlost percentages and the concentration of championships); momentum (or serial correlation); league rules with regard free agency, restricting entry and expansion; crosssubsidization schemes such as reserve and draft systems, caps and revenue sharing; and the connection between payroll and performance.

Important comparisons between baseball before and after free agency, before and after the 1994-95 players' strike, and with other professional team sports, have appeared in the literature in recent years (Horowitz (1997), La Croix and Kawaura (1999), Depken (1999), Vrooman (2000), Eckard (2001A, 2001B), and Zimbalist (2001)). In its first three years of existence, the Journal of Sports Economics published five separate articles 
plus an entire special issue on competitive balance. ${ }^{14}$ For English soccer, Szymanski (2001) has shown that the growing financial disparity among clubs has had no impact on imbalance. How closely payroll and/or market size correlate with winning, including, of course, the determination of the causal relationship, is arguably one of the most important questions about competitive balance. It is also essential to evaluate the relationship between market size and team payroll, which often inaccurately is assumed to be tight.

More popular accounts from sports commentators, reporters and fans may lack the economists' technical sophistication, but they substitute the appeal earlier applied by some to pornography - they can't define balance formally or precisely, but they recognize it when they see it, and they are convinced they don't see it now. The Blue Ribbon Report (BRR) noted that recently baseball teams with the largest payrolls dominate post-season play. Its authors observed that all eight playoff teams in 1999 were among the top 10 in payroll, the Dodgers and Orioles being the only exception. The BRR reported (page i) that: "From 1995 through 1999, a total of 158 postseason games were played.... During this five-year period, no club from [the bottom half of the payroll distribution] won a Division Series or League Championship Game." ${ }^{15}$ It also noted the positive relationship, in theory and practice, between winning percentage and market size, concluding that large-market teams are likely to emerge disproportionately at the top of league standings and in the distribution of championships. ${ }^{16}$

Sports columnists have devised their own competitive balance criteria. Allen Barra (2002A) has proposed two complementary competitive imbalance measures with regard to post-season play: the number of different franchises that make the playoffs, and the number of different teams that play for a championship. Comparing MLB to the NFL 
and the NBA, Barra noted that in spite of fewer available playoff spots, over the last two decades 20 franchises have appeared in the World Series, compared with 19 in the Super Bowl and 15 in the NBA finals. Since 1996, the period of heightened concern about imbalance in baseball, approximately the same number of different teams have appeared in the World Series as in championship series in the other two leagues. In Clearing The Bases (2002B, Chapter 13), Barra adds a third metric: the number of teams in baseball that finish the regular season with better than a .600 or worse than a .400 winning percentage, arguable standards of domination and futility, respectively, that he notes have been met by fewer and fewer teams over time. ${ }^{17}$

To the extent that fan demand is a function of a possible competitive outcome on any particular occasion as opposed to an entire season or in the hunt for a championship, in baseball the premier team in any season loses about four games in 10, and generally fares worse on the road than at home. In the 2000 season, for example, the World Champion New York Yankees lost 74 games, almost 46 percent of their contests. They swept only six of the 39 three-game regular season series they played that year; thus "Yankee haters" had a reasonable probability of having their own team prevail on any given night or any trip the Bronx Bombers made to town.

\section{THE NATURAL DEMAND FOR AND SUPPLY OF BALANCE (AND IMBALANCE)}

Apart from the constraints leagues place on competition to ensure balance (factors discussed later), which may have the complementary effect of increasing and/or redistributing revenues, there are also natural forces that influence the distribution of outcomes. One obstacle to reducing inequality in sports leagues could be, paraphrasing 
Pogo, that we may not only be content with the current imbalance but also actually prefer it to the alternatives. Or, at a minimum, we are conflicted and willing to let natural (and unnatural) forces and inertia, rather than explicit interventions, determine outcomes. In economic and sporting walks of life, we have a preference for a positive correlation between effort and reward. To reward the statistically better individual or team for its prior achievements we tip some balances in its favor - playing more games at home, higher seeds or a better lane, an extended playoff series rather than a single winner-takeall contest. The more evenly matched two opponents are, the higher the probability that a random element - a poor call by an official, a bad bounce, a key injury, or pure luck will determine the outcome. ${ }^{18}$ Thus, the premise that the demand for games is greater, ceteris paribus, the greater the degree of uncertainty conflicts with our sense of justice that the better team win. Luck is the way we account for the success of people and teams we don't like, but it is not a factor that we generally want to determine our income distributions in society or our champions in sporting contests.

On the other hand, we have strong identifications with and sympathies for the true underdog. We want David to knock off Goliath, at least on occasion (unless, of course, Goliath plays for "us" - Chicago was quite content with the Bulls' domination in the 1990s, and Yankee fans have few quibbles with the alleged imbalance in baseball). Nowhere is this better exemplified than in popular sports movies that feed off imbalance. Films such as "Rocky," "Hoosiers," "The Mighty Ducks," and "Major League" cater to these instincts. (And, after all, the play was called "Damn Yankees," not "Damn Cubs.") As much as one may loathe a bully, selling tickets to an event in which he has some 
chance of being upset is marketable. Dynasties, storied franchises, such as the Yankees, Celtics, Packers and Red Wings are not without their advantages in terms of fan interest.

The world is replete with examples of healthy inequality more extreme than the current levels in baseball. State lotteries are popular despite daunting odds. While just 25 of the nation's 400 graduate schools grant a third of all new Ph.D.s each year, the "industry" maintains diversity and vitality while competing implicitly head to head. Other comparable concentrations and inequalities abound - live theater, world-class symphonies, and first-rate art museums are not evenly distributed across the landscape.

In sports, virtually all teams win at least a fourth of their games and few win more than two-thirds of the time. Victories - and losses - are not inevitable. In leagues with 30 teams, the probability of winning the ultimate prize - a World Series or Super Bowl with equal distributions of talent in any given year is 0.033 ; thus a team or city could expect to garner a championship about once a generation. The difference between that periodicity and a "dynasty" can be as little as a factor of three, in that in the latter instance a team may win a championship once a decade instead of once per generation.

Sports' fans' memories are selective and the rate at which they fade appears to be small. That a team last won a Super Bowl or World Series more than a decade ago may seem like yesterday. (Many Chicago fans think of the Bears as a championship team, even though their only Super Bowl win occurred in 1986.) Stadiums and arenas are replete with banners from past conquests, in most cases many years removed. Fans don sweatshirts and caps that evoke past memories as much as current realities. That, coupled with our basic "hope springs eternal" (or "wait until next year") spirit, fueled with optimism about the most recent draft choice or free-agent acquisition, buoys the soul - 
and ticket sales. Scully's (1995) empirical validation of serial correlation in sports and his admonition that fans should be patient reinforces our natural instincts and outlooks. In a society that confronts substantial inequality in its daily experiences, the current level of imbalance in baseball may not be intolerable.

In addition to these many factors contributing to the observed inequality of outcomes, whatever the metric, there are several other possible explanations for competitive team imbalance. The following examples are but a few such considerations.

\section{Differences in Population and Preferences}

The demand for beachwear in Ft. Lauderdale dramatically exceeds the demand for swimsuits in Buffalo and also in St. Augustine, yet no one seems to worry about bikini imbalances. Indeed, we would probably be puzzled if such sales in Ft. Lauderdale did not exceed combined receipts in Buffalo and St. Augustine by a large margin. Although the populations of Buffalo and Ft. Lauderdale are similar, the per capita demand for bathing suits is greater in Florida than in upstate New York, presumably because of greater utility in use. And, although St. Augustine and Ft. Lauderdale share the same climate and accessibility to beaches, the population of Ft. Lauderdale is many times larger than St. Augustine. Geographic differences and preferences exist with regard to types of foodstuffs consumed, automobiles driven, and television programs watched.

So, too, for winning sporting contests. Residents in some locations may be willing to pay more to have a more successful local team (e.g., per capita willingness and ability to support a winning ice hockey team undoubtedly is greater in Ontario than in Florida), especially if there are fewer other recreational, entertainment and/or cultural 
amenities close at hand. Population disparities across areas hosting teams can create differences in aggregate willingness and ability to pay even when individual customers in the various host cities have identical tastes.

These differences could be equalized if teams in sports leagues were free to move to areas where the marginal revenue per win is higher than their initial location. The resulting competition among teams in the same league within a metropolitan area would dilute the incremental revenues earned by the original incumbent, and reduce financial disparities among the teams. The collection of Australian Rules football teams in Melbourne, the concentration of baseball teams in Tokyo, and the density of premierleague soccer teams in London illustrates the possibility.

Team movements that would help to equalize marginal revenues do not occur, however, because each of the professional men's team sports leagues in North America exercises a form of collective control over member team movements. Incumbents in the larger cities or those cities where fans are willing to pay more for winning are loath to share their revenues with immigrants from smaller communities or from locations where success on the playing field is less important to the residents. They are protected from incursions either by league constitutional provisions protecting their "home territory," or by their ability to form coalitions sufficient to prevent other teams from moving into their host community. In short, the competitive imbalance that emanates from the monopoly control of home territories by incumbents arises from the conduct of the leagues' member teams themselves because they are unwilling or unable to introduce competition into areas where favored incumbent teams earn considerable economic rents. Revenue 
disparities among franchises in professional baseball would diminish if the Montreal Expos were permitted to move to northern New Jersey. ${ }^{19}$

These disparities, and even the "large market" versus "small market" distinction, would disappear if expansion occurred within an existing cartel league, a rival league formed, and/or some judicial action broke up the cartel (as the resulting smaller leagues, in search of new markets, spawned new franchises). ${ }^{20}$ New York City is considered a large market and Kansas City a small one in part because the ratio of teams to population is so dissimilar. Migration of existing franchises and/or the creation of new ones located in larger metropolitan areas would equalize these ratios in sports leagues much as the way in which retail establishments and other social amenities equalize in more traditional, competitive markets, like fast-food outlets and swimsuit retailing.

\section{Willingness to Act on Differences in Fan Tastes}

In addition to different preferences for winning, fans who live in different areas may differ in their willingness to act on those preferences (Porter, 1992). The more fickle are fans, the more their willingness to buy tickets depends on the local team's onfield success, the greater is the marginal revenue from the local team's winning additional contests, and the greater is the incentive for a team to expend resources to secure more highly skilled players. A profit-maximizing league could exploit fickleness by strengthening teams located where fans are less loyal and, in turn, weakening teams where fans will turn out regardless of the success of the local franchise. This would not bode well for the Cubs and Steelers. If a league did this, however, the distribution of 
playing talent could be inefficient because it is configured in response to fans' willingness to act on their preferences rather than on the basis of the preferences themselves.

Moreover, in addition to caring about the on-field success of the home team, fans often have preferences regarding dominance that are independent of which team dominates. That is, the competitive balance distribution itself is a public good. Everyone must live with the same overall distribution, and individuals may have strong preferences about the shape of that distribution. Some may prefer imbalance, even sufficient to create dynasties, whether they love them or love to hate them. Others may prefer a league in which almost all teams win about half of their contests.

While fans may have views on what the general distribution of competitive balance should look like, these views may fluctuate over time. As the real income levels of sports consumers have risen over the second half of the twentieth century (Siegfried and Peterson, 2000), and the typical fan has moved further up an increasingly disperse income distribution, fan preferences toward the overall distribution of competitive balance conceivably could migrate toward more imbalance in game outcomes as well.

\section{Differences in Player Tastes}

Differences in team playing skills can arise even if there are no differences in the population base of team territories, in fan fickleness, or in fan preferences toward home team winning or dynasties because players also have preferences. Players may have a preference for living in certain areas (e.g., Florida or Southern California) and be willing to sacrifice part of their salary in order to do so. ${ }^{21}$ Or they may see more lucrative endorsement opportunities in areas with relatively stronger media markets. Ken Griffey, 
Jr. apparently accepted a lower salary than he could have earned elsewhere to sign a contract to play in his hometown of Cincinnati; the Mariners were attractive to John Olerud because of family ties in Seattle - and Lou Pinella engineered a move from Seattle to Florida to manage closer to home. Wayne Gretsky precipitated his trade to Los Angeles to accommodate his wife's acting career. And on the other side, Steve Francis announced he was never going to live in Vancouver, and so stimulated the (then) Vancouver Grizzlies to trade him to the Houston Rockets.

Network economies can also affect the distribution of playing talent. Players may accept a lower salary to be on a team with greater odds of winning a championship, thereby further enhancing the talent of the contender. Ray Bourque approved a trade from the Boston Bruins to the already powerful Colorado Avalanche late in his career to boost his chance of playing on a Stanley Cup championship team, a goal he achieved in 2001. Greg Maddox's self-relocation from the Cubs to Braves is another example.

Consider, in the extreme, how players might distribute themselves across teams if their salaries were zero. Would they join teams so as to balance playing talent? College football and basketball may provide some guidance as to what might happen because players' compensation is relatively constant across universities. There the attractive new prospects gravitate toward perennial winners in order to enjoy greater prospects for onfield success, to play with more talented teammates, and to gain more media exposure.

\section{The Tradeoff between Winning and Uncertainty}

Competitive balance is thought to affect attendance of fans through its influence on winning and fans' response to winning. It is well established that home attendance 
rises when a team wins more games or matches, and declines when it loses. ${ }^{22}$ Winning teams also attract more fans when they play on the road. The Yankees attract a crowd when they visit other American League cities, whether it is because fans love to hate a winner, wish to see marquee players, or the Yankees have a following in other locations. As the mobility of our population has increased in the post World War II years, fans of particular teams more frequently reside outside their home territory. Similarly, "superstation" broadcasts have created national Braves and Cubs fans. While that phenomenon does not affect home attendance much, it can affect away attendance and television ratings. The extent to which owners of stronger teams take these factors into account depends on league rules for sharing gate and television revenues. The Detroit Red Wings draw huge crowds on the road because they are an elite team of established (read: older) talented players, and because former residents of Detroit maintain their affinity for the team and attend games that the Red Wings play on the road. This generates incremental revenue for other National Hockey League teams, but does not affect incentives facing the Red Wings management because in the NHL visiting teams do not share in gate receipts and there is little national television revenue.

Competitive balance may also affect attendance negatively at games among teams that are relatively weak because fans view them as "out of the running" for a championship (as opposed to any individual contest on any given day). If this occurs when the revenue sharing rules are confined largely to home and visiting teams, the owners of the higher revenue teams may ignore the external impact of imbalance on the league's overall revenues until it reaches the point where the integrity of the overall competition is called into question and fans abandon the sport altogether. The addition of 
wild-card teams and smaller divisions or conferences, which both increase the number of teams eligible for the playoffs, are innovations designed to retain fans across more cities longer into the regular season by increasing the uncertainty of ultimate outcomes.

\section{Character of the Events Themselves}

In the 1980s and 1990s, responding to fan demand driven in part by higher incomes, professional sports franchises repositioned their product by increasing the emphasis on complementary, non-contest services and amenities, blurring further the distinction between sports and entertainment. (The short-lived XFL may have overshot that moving target.) Although the Dallas Cowboys Cheerleaders pre-date the 1980s, they are a vivid representation of the movement. New stadiums that include upscale restaurants, batting cages and other amusements for children, museums, Jumbotron scoreboards with instant-replay and promotions, fireworks, and even a swimming pool (in Phoenix), reduce the relative importance of the game in the overall recreational package. Intermission entertainment at basketball, ice hockey, and football games is now standard fare, including contests for fans, mini shows by well-known musical artists, trampoline groups, and scoreboard video clips. Even the Montreal Forum has abandoned the traditional fare of just a Zamboni machine doing the ice between periods of NHL contests, and the New York Islanders have replaced traditional ice-maintenance workers (read: middle-aged, overweight males in parkas) with navel-baring young women in Lycra outfits. ${ }^{23}$ Luxury boxes and exclusive access areas increase the value of "being seen" at the game relative to seeing the game. 
As the relative importance of the game itself diminishes in the entertainment package, competitive balance becomes a less important determinant of demand. So long as the tendency to broaden the entertainment experience is similar across locations of differing revenue potential, however, this phenomenon, like revenue sharing, should not have more than a modest effect on competitive balance.

\section{Complementary Economic Theory}

Traditional economic arguments for what prevents one owner from amassing an all-star line-up in an effort to win every contest and the championship turn on notions of self-interest and the inevitable diminishing marginal returns to, and the increasing marginal cost of, victories. Hence some natural mechanisms constrain the extent of imbalance in most leagues. That assumes, however, that there are both effective ways to blunt possible negative externalities, and that owners, deep down, are profit maximizers.

Common practices within sports leagues to ensure some semblance of a "level playing field" with regard to the distribution of talent across teams - reverse-order draft systems, various attempts to constrain players' salaries, revenue sharing - are also at odds with how economic theory generally views "peer effects" and the optimal sorting of workers. Where spillovers are significant, high ability workers are more valuable to other high quality workers, and workers should be more homogeneously sorted. ${ }^{24}$ The "assignment problem" involves how to sort heterogeneous units into groups so that output is maximized. ${ }^{25}$ Whether in general production processes, law firms, or marriages, higher ability workers, colleagues or spouses are more productive when grouped with other high ability people. Because similar quality workers are more productive when sorted into the 
same firm, a firm with higher quality workers may not be willing to employ lower quality workers even if those workers would work for less pay.

The general application of this sorting principle in sports implies, for example, that an all-star shortstop's productivity is higher if he is paired with an all-star second baseman. Moreover, on-the-field traits carry over into the clubhouse and social settings, where discipline, motivation, attitude and joint-monitoring can be important as well. If this proposition is true, practiced in sports it would lead to inequality in the distribution of talent - some teams would have good players, other teams poor ones, and competitive imbalance would emerge. (Within baseball organizations, the farm system may serve as a sorting mechanism, and across-team trades and free-agent signings may represent, in part, attempts to capture potential peer-effect gains.) In some sense, then, sports leagues may be fighting an uphill battle in trying to stem the tide of nature and market forces pushing toward imbalance.

\section{INSTITUTIONAL ARRANGEMENTS AND COMPETITIVE BALANCE}

Many institutions or off-the-field rules of the game are negotiated every time a Collective Bargaining Agreement (CBA) is renewed. These changes may affect the degree of competitive balance in any professional sports league.

\section{Payroll Caps and Luxury Taxes}

Payroll caps, and so-called "luxury taxes" on payrolls, create an incentive for owners of teams in higher revenue locations to hire less talent than they would in the absence of these constraints. In the extreme, a binding ceiling on total payroll limits the 
amount of talent a high revenue team can accumulate. As a by-product, a firm payroll cap also increases the profits of high revenue teams. Its impact on competitive balance depends on the extent to which the cap is below the free-market payroll level of the highest payroll team that also dominates on the field (read: Yankees).

One danger of payroll caps is that they may be porous (e.g., the NBA cap that includes a well-known loophole - the "Larry Bird" exemption - designed to preserve team unity, or the NFL, in which for 2002 accounting conventions permitted virtually every team in the league to be over the cap), and they create a temptation for violating the rules (e.g., the Minnesota Timberwolves paid a large fine for paying Joe Smith "off the books" in excess of the cap). A system in which cheaters are more successful than those who play by the rules may be even less inviting than one in which teams fortunate enough to own rights to high revenue areas are more successful. Moreover, payroll (and salary) caps do not extend to complementary inputs, so successful coaches - Jon Gruden, Dusty Baker, Phil Jackson - can command a sizable sum for managing a team on which the total payroll, and even individual salaries, may be frozen.

A less drastic version of the payroll cap is what has come to be known in professional sports as a "luxury tax" on payrolls, first enacted in baseball for three seasons (1997-99) and reinstituted in the 2002-2006 agreement as a 17.5 percent penalty on payroll amounts exceeding $\$ 117$ million for the 2003 season. ${ }^{26}$ The rationale is that fielding a highly paid team is a "luxury" for one owner that imposes negative externalities on other franchises. This makes sense if the tax becomes effective at the point where incremental talent on the high revenue team creates a league-wide net negative impact that might be ignored by the owner of the high revenue team because 
under league revenue sharing rules he or she bears little of the cost of an "overaccumulation" of talent. If the tax rate accurately reflects this internal "externality," it creates an incentive for the high revenue team owner to balance his or her gain against the cost to third parties. The trick, of course, is to impose the tax rate at the proper payroll level, and to fix the rate such that it internalizes the externality.

To be accepted as "fair," luxury tax revenues usually compensate those who bear the burden of the externality. This tax in MLB is, indeed, structured properly to achieve these goals, although no one knows whether the threshold payroll, the tax rate, and the beneficiaries of the redistribution are properly identified.

\section{Salary Caps}

The NBA is the only U.S. men's professional sports league currently using individual player salary caps to control team expenditures. Maximum salaries are based on seniority in the league. Salary caps emerged from the NBA's collective bargaining with the players' union in 1998 and early 1999, at least partly in reaction to the league's leaky team payroll cap.

Individual salary caps limit a team's payroll to the product of the roster size times the cap for the most senior players, not a significant constraint. Individual salary caps based on seniority are unlikely to have much of an impact on competitive balance because a high revenue team can sign a complete team at the highest allowed salary, thereby accumulating an entire team of the most desirable players in the league. This is not likely to happen, however, because the most expensive team one can buy is also an old team. A team can assemble a more competitive roster paying less than the maximum. 
If league rules constrain salaries, free agent players' choices of which team to join will turn more on their personal preferences, including desirable places to live and prospects for endorsements and a championship. Individual salary caps are likely to increase competitive imbalance because they encourage players to rely more on their preference for joining a winning team than on differences among salary offers. Salary caps will, however, limit the payroll of the high revenue teams, because they are the teams that would have bid above-cap salaries to acquire the more talented players. Individual player salary caps probably help the highest revenue teams increase both their profits and their playing talent.

\section{Revenue Sharing ${ }^{27}$}

Revenue sharing reduces the financial incentive of each franchise to acquire more talent, because the payoff to winning is constrained by the share paid to other franchises. Sharing revenues that are sensitive to playing success blunts the incentive to win for all franchises - those in low revenue potential locations as well as those in New York.

Because the demand for winning may vary across communities with the intensity of competition for playing talent (fans in some communities find it more satisfying to win when there is a dogfight for talented players), revenue sharing can affect competitive balance. If fans in high revenue potential locations are relatively more sensitive to winning when competition for players (from all teams) is more intense, then increased revenue sharing will improve competitive balance, because the incentive to acquire better players will be muted further for high revenue potential teams. Of course, if the fans in high revenue potential locations are less sensitive to winning when competition for 
players is more intense, then expanded revenue sharing will exacerbate competitive imbalance. Contrary to popular belief, the effect of revenue sharing on competitive balance, while likely modest, could go in either direction.

If revenue sharing blunts the incentive for all teams to bid aggressively for talented players, thereby muting salary differentials between more and less talented players, non-pecuniary considerations will loom larger in free agents' decisions among competing offers. If players value the opportunity to play on championship contenders for reasons beyond financial rewards, increased revenue sharing thus could lead to greater competitive imbalance, a result likely to surprise many people.

The premier men's professional team sports leagues engage in a variety of revenue sharing arrangements. The NFL is the most socialistic, sharing revenues from its huge national television contract and merchandise sales (almost) equally, and gate receipts 66-34 to the home and visiting teams.

The two baseball leagues modestly share local revenues. Ice hockey and basketball share the fewest revenues; in both the NHL and NBA the home team retains all gate receipts. A relatively new wrinkle in baseball is "dynamic pricing" (called "variable pricing" in the press), long a feature in other industries, including airlines and hotels, through which ticket prices vary not only by quality of the seat location but also by day of the week, month, and, now, opponent. In the 2002 season, for example, the Colorado Rockies charged higher prices when the Yankees and Giants played in Denver than when the Brewers visited. More baseball clubs implemented such pricing for the 2003 season. The Chicago Cubs' 2003 schedule listed Wednesday and Thursday day games in April against the Expos and Padres as "value" dates; summer weekend games 
versus the Cardinals, Yankees and White Sox are "prime home games," with prices to match. To the extent that Kansas City can charge fans more for a popular opponent like the Yankees, this represents implicit revenue sharing that narrow inequality in team revenues across a league and thereby promotes more competitive balance.

\section{Number of Teams and Relocation Restrictions}

Just a few days after the 2001 World Series, Major League Baseball announced a plan "contract" in order to ameliorate the effects of competitive balance. Missing from the analysis was a theory relating the number of teams to competitive imbalance.

Presumably the theory is that lopping off the bottom of any distribution tightens it up. Of course, lopping off the top would also tighten it up. And while it is not reasonable to suggest that MLB contract by eliminating the New York Yankees and Atlanta Braves, although that would certainly have an effect on competitive balance not unlike disbanding the Montreal Expos and the Minnesota Twins, an even better alternative would be to let the Expos and Twins move into the New York metropolitan area. A movement from low revenue potential to high revenue potential locations would certainly improve competitive balance, the objective identified by MLB, more than would just eliminating two cellar-dwellers. Indeed, the core of the competitive imbalance problem is the differences in population and tastes for sports across metropolitan areas coupled with each league's artificial restriction on team movements. Let the teams move to wherever they like and the differences in revenue potential will dissipate and

competitive balance will improve. ${ }^{28}$ Yes, high revenue potential teams will be less 
profitable, but if protecting the profits of teams fortunate enough to have the largest demand for their local monopoly is the goal, then explain the contraction on that basis.

To the extent that a competitive balance targeted policy also affects profitability by restraining team payrolls, it may also affect the number of teams. Limitations on team payrolls make lower revenue potential locations viable prospects for joining the league and, in turn, tempt owners, who pocket league initiation fees, to expand the number of marginal franchises and, thus, by their own conduct, reduce competitive balance.

\section{Reverse-Order Player Drafts ${ }^{29}$}

Reverse-order "rookie" drafts, long a staple in many leagues, may have a modest effect on competitive balance, but in baseball it is indeed modest. The difference among teams in drafting is at most one player per year: The worst team in a 30-team league drafts first and $31^{\text {st }}$, and the best team drafts $30^{\text {th }}$; thus beyond the first round there is no draft advantage to the worst team relative to the best. The net gain in terms of balance is simply one player, which in baseball cannot usually make a substantial difference. ${ }^{30}$

To the extent that teams are free to transfer player contracts, the initial allocation of property rights - whether to the worst team in the league or the best team in the league - implies no difference in the ultimate allocation of player resources, and, hence, competitive balance. Unless there are constraints on player sales, a player new to the league who is expected to generate greater marginal revenue product at a franchise with high revenue potential than at one with low revenue potential will end up playing for the high revenue potential franchise, either by initially signing with it, or because the lower revenue potential franchise sells his contract to the high revenue potential franchise. 
A considerable number of empirical tests of the Coase Theorem were spawned by the change in property rights over players that occurred during the 1970 s, when players with a certain amount of seniority gained the rights to "free agency." ${ }^{31}$ Most of these studies concluded that the transfer of property rights from teams to players did not affect the distribution of playing talent, although it did raise player compensation levels.

\section{Other Revenue Enhancements}

Luxury box revenues, stadium naming rights, field advertising, and other local revenue sources can affect competitive balance if they are not proportional to other revenues among teams. If stadium naming rights and luxury box revenues, for example, constitute a higher ratio to gate receipts for higher revenue potential teams, these added revenues will increase the disparity among teams and may exacerbate competitive imbalance. On the other hand, naming rights and luxury box revenue are not likely to be sensitive to team performance. Although a team in a high revenue potential location may enjoy more of these peripheral revenues than one in a lower revenue potential area, unless the revenue is linked to improved team performance on the field, there is no incentive for the team to spend the revenue enhancement on improving its talent level.

\section{Structure of the Competition}

Much in the same way that financial arrangements can affect balance among competitors, so too can the nature and structure of the contests themselves. ${ }^{32}$ How pole positions in auto racing, lane assignments in swimming, brackets in tennis tournaments, or starting gates in thoroughbred races are determined can influence outcomes. In team 
sports, comparable issues turn on how home field, court or ice is established for contests, and the length of the series.

Lengthening a series reduces the probability that the weaker opponent will win; increasing the number of playoff rounds and the percentage of teams eligible for a championship reduces the chances that the best team will capture the championship (Sanderson, 2002). Phil Rogers, baseball analyst for the Chicago Tribune, notes that with the advent of divisional play in 1969, teams with the best regular-season record over 162 games have fared relatively poorly in the playoffs. Since 1990, only the 1998 Yankees won a World Series after finishing with the best record during the season, and only five times out of 12 have teams with the most wins during the season even made it to the Series. Since 1969, only eight teams with the best season record have won the World Series. ${ }^{33}$ In the three years 2000-2002, the team with the better record has won only twice in 17 series (Rogers, 2002). Reducing the number of playoff teams, say, by reverting to only one AL and one NL division in baseball, with the winner of each league meeting in the World Series, would ensure that the teams with the best regular-season record met for the championship, but would entail serious tradeoffs - a loss of excitement late in the season and forgone playoff revenues, for example.

In baseball, about a quarter of teams make the playoffs, compared to about half the teams in the other three professional men's team sport leagues. If baseball were to emulate ice hockey, football, or basketball with regard to the number of playoff-eligible teams and playoff rounds, the probability that the team with the highest payroll would appear in, or win, the World Series would be lower, thus dampening its owner's incentive to spend money for talent, and probably producing more balance across teams. ${ }^{34}$ 
A final "macro" structural change that would replace the weakest teams with stronger ones, long familiar in soccer (European football), is the operation of open leagues, with promotion and relegation. Closed leagues, when combined with reverseorder drafts and revenue sharing, tend to reward failure and punish success, whereas open leagues reward success and punish failure. (See Dobson and Goddard, 2002; Noll, 2002; and Rosen and Sanderson, 2001.)

\section{WHY IS ALL OF THIS SIMPLY A BASEBALL PROBLEM?}

In Major League Baseball over the last 20 years ${ }^{35}$, a free-agency period, 20 different teams have played in a World Series, and 14 different teams have won at least one championship. For the previous 20 years, largely pre-free-agency, 14 different teams played in a World Series and 10 won titles. From 1981-2001, the Yankees appeared in a World Series six times, winning four; the Atlanta Braves won once in five tries; the Oakland A's and St. Louis Cardinals each played in three Series and won once; no other team appeared more than twice. For the previous 20-year period, the Yankees won four times and lost three; the Dodgers won twice and lost four times; and the Orioles and Reds each won two times in five tries. The record shows that in spite of the Yankees' recent success, free agency and high payrolls have not increased the concentration of championships. The two largest markets - New York and Los Angeles, which host two teams each - were represented in World Series competitions 16 times between 1961 and 1980 but only 11 times in the last 20 years. ${ }^{36}$

Still, the Blue Ribbon Report, the commissioner's office, commentators, and everyday fans insist that Major League Baseball has an untenable competitive imbalance 
problem that has worsened since 1995. Proposed remedies include caps on payrolls and/or salaries, more revenue sharing, and even contraction. Needless to say, players and their association (MLBPA) disagree - with both the facts and proposed solutions that would directly or indirectly reduce individual or collective paychecks.

Proposals to bring more balance to baseball often rely on comparisons to professional football and basketball, with their salary and payroll restrictions and/or greater revenue sharing. A more valuable "what if" benchmark may be Division I college football and men's basketball, where there is no free agency and "payrolls" are approximately level. ${ }^{37}$ Outcomes there do not support the conclusion that restrictions on payrolls and other conditions of play would necessarily produce more balance.

For example, in the last 20 years (1981-2000), 17 of the more than 100 Division I football programs have been ranked in the AP (Associated Press) Top 20 nationally for at least 10 years, Nebraska achieving that distinction 19 times. In basketball, 10 programs, led by Duke, North Carolina and Kentucky, account for more than half of all Final Four appearances over the period. When "payrolls" (i.e., tuition, fees, room and board) are approximately the same, non-pecuniary considerations loom larger. A coach, the team's schedule, an institution's track record (i.e., its reputation) with regard to winning and preparing its athletes for professional careers, and other local amenities take on more importance. (At the professional level, flattening payrolls would benefit teams in major markets such as New York and Los Angeles relative to areas with fewer pecuniary opportunities and non-monetary amenities.)

Why is there so little outrage over the domination of selected athletic programs at the collegiate level? Why are we more than willing to countenance more inequality year 
after year in college athletics, other professional sports leagues, and in individual sports, but not in baseball? A few college football programs - Miami, Florida, Florida State, Nebraska, Oklahoma - play in top bowl games most every January; Duke, North Carolina, Kansas, Kentucky, Arizona, and UCLA are the men's basketball counterparts. In NCAA baseball, LSU won five championships in the 1990s, thus exhibiting more dominance than the Yankees in a larger field of competitors. Arkansas has a lock on indoor and outdoor men's NCAA track and field titles. Texas and Stanford dominate men's and women's collegiate swimming and diving. Stanford and Georgia "own" men's and women's collegiate tennis. Iowa has won 19 of the last 20 wrestling championships. North Carolina dominates women's soccer. In 2002, the Connecticut Huskies women's basketball team, winners of four of the last eight national championships, set an NCAA record for women's basketball by winning 55 consecutive games. ${ }^{38}$ Yet we hear few laments about these imbalances. Why is baseball singled out?

More unbalanced achievements prevail in many professional individual sports than in baseball. We revel in Lance Armstrong's "fourpeat" in the Tour de France. Ty Murray has won 8 of the last 12 years' all-around Professional Rodeo Cowboys Association world championships. The concentrations of victories of Tiger Woods and Annika Sorenstam in golf and the Williams sisters in tennis become stories closely followed by the media and fans alike.

\section{CONCLUSIONS}

Of the many contemporary controversies in baseball - ticket prices, owners' financial losses, contentious labor-management disputes, the level and rate of growth of players' salaries, among others - the one that has arguably received the most attention 
recently is the alleged lack of competitive balance. It was the principal focus of the commissioner's Blue Ribbon Report, front and center with regard to proposed provisions of the 2002 Collective Bargaining Agreement, and is a constant theme with the press, public, and economists writing about baseball.

Does competitive imbalance in baseball deserve so much attention? How much of all this is real rather than random? How much confuses a trend with a cycle? How much of the observed outcomes are immutable to policy prescriptions, private or public? Is there anything there beyond four Yankees' titles in a five-year period, and could this be akin to the occasional string of four consecutive heads arising from repeated coin tosses? Would baseball be better off if it looked more like the NFL, or would football trade some of its parity for other dimensions of demand and voluntarily move more toward baseball with respect to competitive imbalance? Some of this is likely to be revealed - and modified - by the time baseball owners and players sit down at the bargaining table in 2006. Until then, questions about relationships between payrolls and performance, city size and winning, uncertainty of outcomes and the level of demand, and the role of player and team mobility in competitive balance will remain a fertile field of dreams for econometricians and commentators alike to hoe. 


\section{REFERENCES}

Akerlof, George. 1976. "The Economics of Caste and of the Rat Race and Other Woeful Tales." Quarterly Journal of Economics. 90 (4). 599-617.

Baade, Robert A. and Allen R. Sanderson. 1997. "Cities Under Siege," in Wallace Hendricks (ed), Advances in the Economics of Sport, Volume 2. Stamford, CT: JAI Press. Pages 77-114.

Barra, Allen. 2002A. "Imbalanced Logic.” The Wall Street Journal. August 30, p. W5.

Barra, Allen. 2002B. Clearing The Bases. New York, NY: St. Martin's Press.

Becker, Gary S. 1973. "A Theory of Marriage." Journal of Political Economy, Part I. 81: 813-846.

Bloom, Matt. 1999. "The Performance Effects of Pay Dispersion on Individuals and Organizations." Academy of Management Journal. 42, No. 1. [February]: 25-40.

Coase, Ronald. 1960. “The Problem of Social Cost." Journal of Law and Economics. 3 [October]: 1-44.

Costas, Bob. 2000. Fair Ball: A Fan's Case for Baseball. New York, NY: Broadway Books.

Daly, George and William J. Moore. 1981. "Externalities, Property Rights and the Allocation of Resources in Major League Baseball." Economic Inquiry. 19 [January]: 77-94.

Depken, Craig A., II. 1999. "Free-Agency and the Competitiveness of Major League Baseball." Review of Industrial Organization. Vol. 14: 205-217.

Dobson, Stephen and John Goddard. 2001. The Economics of Football. New York, NY: Cambridge University Press.

Eckard, E. Woodrow. 2001A. "Free Agency, Competitive Balance, and Diminishing Returns to Pennant Contention." Economic Inquiry. Vol. 39, No. 3, July: 430-443.

Eckard, E. Woodrow. 2001B. "Baseball's Blue Ribbon Report: Solutions in Search of a Problem." Journal of Sports Economics. Volume 2, Number 3. August: 213-227.

El-Hodiri, Mohamed and James Quirk. 1971. “An Economic Model of a Professional Sports League." Journal of Political Economy. 79 [November/December]: 1302-19.

Fort, Rodney. 1992. "Pay and Performance: Is the Field of Dreams Barren?” In Paul 
M. Sommers (ed), Diamonds are Forever. Washington, DC: The Brookings Institution. 134-157.

Fort, Rodney and James Quirk. 1995. "Cross-Subsidization, Incentives, and Outcomes in Professional Team Sports Leagues." Journal of Economic Literature. XXXIII [September]: 1265-99.

Hausman, Jerry A. and Gregory K. Leonard. 1997. "Superstars in the National Basketball Association: Economic Value and Policy," Journal of Labor Economics. Vol. 15, No. 4 [October], 586-624.

Horowitz, Ira. 1997. "The Increasing Competitive Balance in Major League Baseball." Review of Industrial Organization. Vol. 12: 373-387.

Hylan, T.R., Lage, M.J. and Treglia, M. 1996. "The Coase Theorem, Free Agency, and Major League Baseball: A Panel Study of Pitcher Mobility from 1961 to 1992." Southern Economic Journal. Vol. 62 [April]: 1029-42.

Frank, Robert H. and Phillip J. Cook. 1995. The Winner-Take-All Society. New York, NY: The Free Press.

Guryan, Jonathan. 2001. "Estimating Peer Effects in the Workplace: Evidence from Random Pairings In Professional Golf Tournaments." Mimeo.

Humphreys, Brad R. 2002. "Alternative Measures of Competitive Balance in Sports Leagues." Journal of Sports Economics. Volume 3, Number 2; May: 133:148.

Hunt, Joseph W. and Kenneth A. Lewis. 1976. "Dominance, Recontracting and the Reserve Clause: Major League Baseball,” American Economic Review. Vol. 66, 93643.

Kesenne, Stefan. 2000. "Revenue Sharing and Competitive Balance in Professional Team Sports." Journal of Sports Economics. Volume 1, Number 1. February: 56-65.

Koopmans, Tjalling C. and Beckman, Martin. 1957. "Assignment Problems and the Location of Economic Activities." Econometrica. 25: 53-76.

Kremer, Michael. 1993. "The O-Ring Theory of Economic Development." Quarterly Journal of Economics. 108: 551-575.

La Croix, Sumner J. and Kawaura, Akihiko. 1999. "Rule Changes and Competitive Balance in Japanese Baseball." Economic Inquiry. Vol. 37, No. 2, April: 353-368.

Lazear, Edward and Sherwin Rosen. 1981. "Rank-order tournaments as optimum labor contracts. Journal of Political Economy. Volume 89, page 841-864. 
Levin, R.C., Mitchell, G.J., Volcker, P.A. and Will, G.F. 2000. The Report of the Independent Members of the Commissioner's Blue Ribbon Panel on Baseball Economics. New York: Major League Baseball.

Marburger, Daniel. 1997. "Gate Revenue Sharing and Luxury Taxes in Professional Sports. Contemporary Economic Policy. Vol. XV, no. 2. 114-123.

Neale, Walter. C. 1964. "The Peculiar Economics of Professional Sports: A Contribution to the Theory of the Firm in Sporting Competition." Quarterly Journal of Economics. Vol. 78 [February]: 1-14.

Noll, Roger G. 2002. "The Economics of Promotion and Relegation in Sports Leagues," Journal of Sports Economics, Vol. 3, No. 2, May: 169-203.

Porter, Phillip K. 1992. "The Role of the Fan in Professional Baseball," in Paul M. Sommers (ed)., Diamonds are Forever: The Business of Baseball. Washington, DC: The Brookings Institution Press, 63-76.

Quirk, James and Rodney Fort. 1992. Pay Dirt: The Business of Professional Team Sports. Princeton, N.J.: Princeton University Press.

Quirk, James and Rodney Fort. 1999. Hard Ball: The Abuse of Power in Pro Team Sports. Princeton, N.J.: Princeton University Press.

Rogers, Phil. 2002. "Wins don't translate to playoffs." Chicago Tribune. October 13, sec 3 , page 2 .

Rosen, Sherwin and Allen Sanderson. 2001. "Labour Markets in Professional Sports." The Economic Journal. Vol. 111, No. 469 [February]: F47-F68.

Ross, Stephen F. 1989. “Monopoly Sports Leagues.” Minnesota Law Review, 649.

Ross, Stephen F. 2001. “Light, Less-Filling, It's Blue-Ribbon.” Unpublished.

Rottenberg, Simon. 1956. "The Baseball Players' Labor Market." Journal of Political Economy. 64 [June]: 242-58.

Rottenberg, Simon. 2000. "Resource Allocation and Income Distribution in Professional Team Sports. Journal of Sports Economics. Volume 1, Number 1. February: 11-20.

Saint-Paul, Gilles. 2001. "On the Distribution of Income and Worker Assignment under Intrafirm Spillovers, with an Application to Ideals and Networks. Journal of Political Economy, 109: 1-35.

Sanderson, Allen R. 2002. "The Many Dimensions of Competitive Balance." Journal of Sports Economics. Volume 3, Number 2. May: 204-228. 
Sanderson, Allen R. and John J. Siegfried. 1997. "The Implications of Athlete Freedom to Contract: Lessons from North America." Economic Affairs. 17 [September]: 7-12.

Schmidt, Martin B. and David J. Berri. 2001. "Competitive Balance and Attendance: The Case of Major League Baseball." Journal of Sports Economics. Volume 2, Number 2. May: 145-167.

Schmidt, Martin B. and David J. Berri. 2002. "Competitive Balance and Market Size in Major League Baseball: A Response to Baseball's Blue Ribbon Panel." Review of Industrial Organization, 21: 41-54.

Scully, Gerald W. 1989. The Business of Major League Baseball. Chicago: The University of Chicago Press.

Scully, Gerald W. 1995. The Market Structure of Sports. Chicago: The University of Chicago Press.

Siegfried, John J. 1995. "Sports Player Drafts and Reserve Systems." Cato Journal. Vol. 14, No. 3 [Winter]: 443-452.

Szymanski, Stefan. 2001. "Income Inequality, Competitive Balance and the Attractiveness of Team Sports: Some Evidence and a Natural Experiment from English Soccer," The Economic Journal. Vol. 111, No. 469 [February]: F69-F84.

Szymanski, Stefan. 2003. "The Economic Design of Sporting Contests: A Review." Journal of Economic Literature. (Forthcoming)

Utt, Joshua and Rodney Fort. 2002. "Pitfalls to Measuring Competitive Balance with Gini Coefficients." Journal of Sports Economics. Vol 3, No. 4 November

Vrooman, John. 1995. "A General Theory of Sports Leagues." Southern Economic Journal. [April]: 971-990.

Vrooman, John. 2000. "The Economics of American Sports Leagues." Scottish Journal of Political Economy. 17 [September]: 364-398.

Walker, Sam. 2000. "Hockey's Vision in Lycra." The Wall Street Journal. November 1. Page W4.

Whitney, James D. 1993. "Bidding Till Bankrupt: Destructive Competition in Professional Team Sports." Economic Inquiry. Vol. XXXI, January: 100-115.

Zimbalist, Andrew. 1992A. Baseball and Billions. New York, NY: Basic Books. 
Zimbalist, Andrew. 1992B. "Salaries and Performance: Beyond the Scully Model." In Paul M. Sommers (ed), Diamonds Are Forever. Washington, DC: The Brookings Institution. 109-133.

Zimbalist, Andrew. 2001. "Competitive Balance in Major League Baseball." The Milken Institute Review. Vol. 3, No. 1. [First Quarter]: 54-64.

Zimbalist, Andrew, Guest Editor. 2002. "Symposium: Competitive Balance in Sports Leagues." Journal of Sports Economics. Volume 3, Number 2. May.

Zimbalist, Andrew. 2003. May The Best Team Win. Washington, DC. The Brookings Institution Press.

Allen R. Sanderson is associate chair and senior lecturer in economics at the University of Chicago.

John J. Siegfried is Professor of Economics at Vanderbilt University and Secretary-Treasurer of the American Economic Association. 


\section{NOTES}

${ }^{1}$ We are indebted to Brad Humphreys for thoughtful comments on an earlier draft and to Rod Fort, Steve Ross and Andy Zimbalist for reactions to the version presented at the conference.

${ }^{2}$ See also Rottenberg, 2000.

${ }^{3}$ See also Whitney (1993).

${ }^{4}$ Protests of the New York Yankees' payroll in 1999 included Kansas City fans turning their backs when the Yankees came up to bat, and then filing out of Kauffman Stadium in the third inning. Similar greetings accompanied the high-salaried Alex Rodriquez in 2001, when he returned to Seattle now as a member of the Texas Rangers.

${ }^{5}$ The Yankees have won four World Series in the last seven years and 26 in all, though prior to 1996, they had not been in a World Series since 1981 and had not won one since 1978. That club's on-field fortunes were cited in Rottenberg's seminal article to illustrate the impact, of lack thereof, of the reserve system on the distribution of playing talent in baseball. However, that the Yankees have won 26 of the 38 World Series they have played in - a statistically significant 68.4 percent - may attest more to their grit and guile than it does to their payroll. (From 1991 to the present, the Atlanta Braves have won their division title 11 consecutive years. However, their only World Series win, in five appearances in the decade, came in 1995.)

6 "Bring Competition Back to Baseball," The Wall Street Journal, April 5, 1999. That same week, pre-tournament coverage of the Masters golf tournament included a similar refrain: "So while 96 players will tee off, far fewer have a realistic chance to win. 'How many have a chance of winning?' said Fred Couples, who won the Masters in 1992, and who tied for second last year. 'Fifty. But realistically, I'd say 10 or 12 guys." [The New York Times, April 8, 1999, C21.] (Three days later, Jose Maria Olazabal, who was not among the favorites, though he had won in Augusta in 1994, won the 1999 tournament.) ${ }^{7}$ Economist and Yale University President Richard Levin, former Senator George Mitchell, former Federal Reserve Board Chairman Paul Volcker, and political pundit and author George Will.

${ }^{8}$ Comments on and criticism of the BRR and its conclusions include papers by Ross (2001), Eckard (2001B), and Schmidt and Berri (2002).

${ }^{9}$ Chicago Tribune, December 18, 2001. Section 4, pages $1 \& 6$.

${ }^{10}$ A century ago, of course, the reserve clause was the principal mechanism employed by owners to allegedly ensure balance; outright collusion that restrained bidding for free agents was the tool of choice in baseball twenty years ago; organizing new leagues, such as Major League Soccer (MLS) and the WNBA, as "single entity" structures is a more recent manifestation of similar goals. Limits on roster size are often thought to enhance competitive balance by preventing some teams from stockpiling talent; however, there is little literature on this subject and scant empirical support for that contention.

${ }^{11}$ The New York Yankees have led the league in attendance - at home and on the road in recent years. The Montreal Expos and Tampa Bay Devil Rays do not draw well at home, nor do they fill ballparks for their away games. During the Jordan era, the Bulls played to sold-out arenas around the NBA, the only team to do so. See Hausman and Leonard (1997) for an analysis of the impact of superstars Larry Bird, Magic Johnson and 
Michael Jordan on attendance and television viewership - and revenues - in the NBA, and the extent of free riding by other franchises.

${ }^{12}$ El-Hodiri and Quirk (1971) also treat this issue in their classic article.

${ }^{13}$ For example, see Siegfried (1995) and Hylan et al (1996). Another early contribution was from Walter Neale (1964).

${ }^{14}$ Volume 1, Number 1, February 2000, articles by Rottenberg; Kesenne; Volume 2, Number 2, May 2001, article by Schmidt and Berri; Volume 2, Number 3, August 2001, article by Eckard; Volume 3, Number 3, May 2002 (entire issue); Volume 3, Number 4, November 2002, article by Utt and Fort; and Volume 4, Number 1, February 2003, contains commentaries on competitive balance by Eckhard and Humphreys.

${ }^{15}$ On the same page of the BRR, it is claimed that: "From 1995 through 1999, only three clubs achieved profitability." This assertion has been questioned by many observers.

${ }^{16}$ Schmidt and Berri (2002) do not find a link between market size and competitive balance. They also contend that the causality between these two factors is ambiguous. In another recent variation on the inequality theme, applying the work of Frank and Cook (1995), Bloom (1999) investigates intra-team pay dispersion and finds, holding total payroll constant, a negative relationship between the degree of inequality in a team's payroll and individual (and thus team) on-field performance. Nevertheless, in baseball at least, the within-team salary inequality, between the minimum and maximum or the range between the median and the highest salary, continues to widen.

${ }^{17}$ In 2000, for the first year in MLB history, no team finished above .600 or below .400 .

${ }^{18}$ Questionable officiating during the NFL playoffs arguably determined Super Bowl opponents in both 2002 and 2003.

${ }^{19}$ Or even to Puerto Rico, where the Expos played a fourth of their 2003 "home" schedule.

${ }^{20}$ See Ross (1989) and Baade and Sanderson (1997) for arguments and proposals for breaking up existing leagues into smaller entities.

${ }^{21}$ Sports commentators have occasionally referred to San Diego's climate, beauty and lifestyle as creating a "Padre discount" in that team's ability to sign players for a lower salary than would be true for, say, the Detroit Tigers.

${ }^{22}$ Szymanski's review of the literature (2003) shows that empirical support for the correlation between winning and demand exists, but that it is weaker than usually assumed. In his 2001 Economic Journal article on English soccer, Syzmanski (2001) finds that match attendance appears to be unrelated to competitive balance.

${ }^{23}$ Sam Walker, "Hockey's Vision in Lycra," The Wall Street Journal, November 1, 2002, W4.

${ }^{24}$ The authors are indebted to Todd Kendall for pointing out this literature and complementary arguments.

${ }^{25}$ See Koopmans and Beckman (1957), Becker (1973), Kremer (1993), Saint-Paul (2001) and Guryan (2001).

${ }^{26}$ See Zimbalist (2003) for lengthy discussions of the labor-management process

surrounding the 2002 Collective Bargaining Agreement.

27 See Marburger (1997).

${ }^{28}$ Of course, the purchased right to operate in "exclusive territories" is commonplace and expected in franchise operations and many other commercial areas, and generally may serve efficiency purposes, not just in professional sports. 
${ }^{29}$ Additional draft dimensions include supplemental drafts, similar to expansion drafts, at the conclusion of regular seasons, and, for MLB, the inclusion of non-U.S. players in the annual amateur draft. We do not treat either of these variations in our paper.

${ }^{30}$ Arguably, the draft could have more of an impact in the NBA, where one player could constitutes 20 percent of a starting line-up and there is more agreement about a player's potential, than in football or baseball, which have larger rosters and predictions of performance are less reliable.

${ }^{31}$ See Hylan et al (1996) and Krautmann and Oppenheimer (1994).

${ }^{32}$ See Szymanski (2003) for a discussion of the design of contests, including the optimal number of entrants, structure of rewards, and amount of revenue sharing and balance.

${ }^{33}$ Remarkably, in 17 of the Yankees' 26 championships they won the final game on the World Series on the road.

${ }^{34}$ Historically, the potential home-field advantage in the World Series - when a series goes the full seven games - has been rotated each year between the two leagues. The commissioner's recent proposal, which owners and players approved, lets whichever league wins the annual All-Star game have that edge in 2003 and 2004, could affect balance. The team with the home-field advantage actually lost the World Series in 21 of the 30 years from 1955-84, including Game 7 a total of 12 times. However, in the last 22 World Series played, the team that has been home for Games $1 \& 2$ (and potentially $6 \&$ 7), has prevailed 18 times (and 15 of the last 17), including the last 8 decided by a seventh game (no visiting team has won Game 7 since the Pittsburgh Pirates in 1979). ${ }^{35}$ 1981-2001; there was no World Series played in 1994 because of the players' strike. 36 The top four teams in the earlier period accounted for 23 of 40 available World Series slots. In the most recent 20 years the four most represented teams comprise only 17 of 40 possible appearances. In the National Football League, 19 different franchises have played in a Super Bowl in the last 20 years, and 12 different teams have won at least once. The San Francisco 49ers have recorded the most wins (4) and the Buffalo Bills lost all four Super Bowl games in which they played. Five franchises account for more than half of the appearances and two-thirds of the wins. In the last 10 years alone, 15 different teams have played in the Super Bowl; none of the six divisional champions from the 2000 season repeated in 2001. Over the last 20 years in the NBA, 14 different teams have played in a championship series and seven of them have won at least once; with six wins each, the Lakers and Bulls account for 12 of the 20 trophies. In the NHL over the same period, 18 teams played in the Stanley Cup Finals, with Edmonton making the most appearances (6, winning 5).

37 There are, of course, some additional differences between the NBA or NFL and their college counterparts, including a university being unable to threaten to relocate if a new stadium isn't forthcoming, the non-profit nature of higher education and, unlike for professional franchises, the more complex, multi-dimensional goals of educational institutions.

38 The men's basketball record for consecutive victories is 88 , set by UCLA in the early 1970s (1971-74); Oklahoma won 47 straight football games in the 1950s. 